\title{
Gauging the Size of Today's Price Shocks
}

\author{
Kevin L. Kliesen
}

M arket-based economies operate best when consumers and producers are not routinely surprised by changes in the price level. Sometimes, price level surprises (shocks) are the unavoidable result of large changes in relative prices that are unanticipated-and energy price hikes are a notable example. Although monetary policy probably has no direct, short-run effect on energy prices, the central bank can help prevent the transmission of such shocks into the rate of ongoing, trend inflation and inflation expectations.

One simple measure of price shocks is the difference between total and core inflation, per Mankiw. ${ }^{1}$ Over long periods of time, total and core inflation are roughly equal because shocks average approximately to zero-i.e., increases and decreases tend to cancel each other out. An important problem for monetary policy is whether such shocks increase core inflation (a proxy for ongoing, trend inflation) or whether inflation expectations are well-anchored by a credible antiinflation monetary policy.

Since the fourth quarter of 2002, total inflation (i.e., the four-quarter percent change in the price index for personal consumption expenditures, PCE) has regularly exceeded core inflation-largely due to the behavior of energy prices. The table compares price shocks in the past few years with those in the 1970s, also a period of unusually large increases in energy prices. That period is often referred to as the Great Inflation. For comparison, the dates most often associated with changes in the trend rate of labor productivity growth1973 and 1995-will be used as breakpoints. ${ }^{2}$

From 1960 to 1972, average rates of PCE and core PCE inflation were roughly equal. Although the average price shock was slightly negative, its standard deviation was about 0.3 percentage points. The worst shock occurred in 1966:Q1, when PCE inflation was 0.64 percentage points more than core PCE inflation. From 1973 to 1995, the relative price of oil experienced major hikes and declines. Although the average shock was only about 0.1 percentage points, its standard deviation was more than 1 percentage point per quarter (the worst shock, in 1974:Q1, was more than 3.5 percent). Not only was inflation high and variable, but food and energy price increases infiltrated measures of core prices more readily than before.

Interestingly, since 1996 the average price shock has increased to about 0.25 percentage, but its standard deviation has dropped by more than half ( 0.48 percentage points). If we focus solely on the 2002-05 period of sharp oil price increases, the average price shock has increased slightly more, with the largest being 1.15 percentage points (2005:Q3). Indeed, since 2002 the average price shock, 0.37 percentage points, is three times larger than the average from 1973 to 1995. Central bankers can take some solace in the fact that the volatility of price shocks has not increased since 2002. Moreover, the standard deviation and the size of the worst price shock have both been about a third as large as those during the 1973-95 period.

Large and persistent increases in energy prices over the past few years have produced sizable price shocks. However, their volatility has been substantially less than that during the Great Inflation. Moreover, these price shocks do not appear to have elevated inflation expectations, as measured by surveys, long-run forecasts, or yield spreads between nominal and inflation-indexed Treasury securities. This finding suggests that today's monetary policymakers have been successful in achieving and maintaining a degree of credibility that was not apparent in the earlier period.

\footnotetext{
${ }^{1}$ N. Gregory Mankiw, "U.S. Monetary Policy During the 1990s," in Frankel and Orszag, eds., American Economic Policy in the 1990s. Cambridge, MA: MIT Press, 2002.

${ }^{2}$ The core PCE price index begins in 1959.
}

Food and Energy Price Shocks, Various Periods

\begin{tabular}{lcccc} 
& $\mathbf{1 9 6 0 - 7 2}$ & $\mathbf{1 9 7 3 - 9 5}$ & $\mathbf{1 9 9 6 - 2 0 0 5}$ & $\mathbf{2 0 0 2 - 0 5}$ \\
\hline Average & -0.03 & 0.12 & 0.26 & 0.37 \\
Std. dev. & 0.29 & 1.05 & 0.48 & 0.53 \\
Worst & 0.64 & 3.58 & 1.15 & 1.15
\end{tabular}

NOTE: Price shocks are defined as the four-quarter growth of the chainweighted PCE price index less the four-quarter growth of the same index that excludes food and energy prices.

SOURCE: Author's calculations. 